\title{
THE EFFECT OF NURSE PERCEPTION IN WORK INCENTIVE AND SATISFACTION SYSTEMS ON ORGANIZATIONAL CITIZENSHIP BEHAVIOR: A CASE STUDY AT GOVERNMENTAL HOSPITAL
}

\author{
Sinambela Metti Wiradika Charolyna* \\ Business School, Bogor Agricultural Institute, Bogor, Indonesia
}

Panjaitan Nurmala K.

Faculty of Human Ecology, Bogor Agricultural Institute, Bogor, Indonesia

\section{Dirdjosuparto Sukiswo}

Faculty of Economics and Management, Bogor Agricultural Institute, Bogor, Indonesia

*E-mail: mettiwiradika@gmail.com

\begin{abstract}
Hospital is a health service provider organization which always strives to provide satisfactory services so that customers continue to seek the Hospital's services to obtain the required health services. A hospital also demands loyalty from its employees. Therefore, behavior outside the job description (extra role) of the nurse is necessary in a hospital. One of the extra-role behaviors expected of the nurse by the hospital is organizational citizenship behavior (OCB). This study aims to analyze the influence of nurses' perceptions on incentive systems and job satisfaction on OCB. The number of respondents studied was 100 nurses in the inpatient care using a purposive sampling method. The method used in this study was structural equation model (SEM) with the partial least square (PLS) approach using SmartPLS 3.0 software. The results has shown that the perception of the nurses on the incentive system had an effect on the OCB through job satisfaction, so that a positive perception of the nurses on the incentive system would result in higher job satisfaction that would improve OCB.
\end{abstract}

\section{KEY WORDS}

Job, satisfaction, nurses, nurse perceptions, incentive system.

Increasing competition in the service businesses is a challenge for companies to continue to develop and innovate. In order to compete, companies must have better performance. Improving company performance can be done by managing human resources $(\mathrm{HR})$ so that they are interrelated with every part of the company. HR also has a very important role to play in a company. HR with good and reliable performance can make or break a company in competing and maintaining its existence in the business world. Continuous improvement in employee performance is also applied to companies engaged in services, such as hospitals.

The increasing intensity of competition and the number of competitors requires hospitals to always pay attention to the needs and desires of customers by providing more satisfying services than their competitors. Thus, only quality companies can compete and dominate the market (Atmawati and Wahyuddin 2007). Therefore, a hospital seeks to provide satisfactory services so that customers continue to seek the Hospital's services.

Service quality is a measure of how precise the level of service offered by a company or service provider can meet customer service standards. This is because the performance of the company at that time is entirely determined by employee performance in determining whether customers will seek the service again at the next opportunity (Gronroos 2000).

In the hospital industry, nurses are the largest human resource that organizes health services in the form of nursing care in hospitals. The nursing team is a prominent aspect of healthcare that cannot be excluded from all forms of the hospital services. Nurse's 
performance plays an important role in the success of a hospital in providing quality and satisfying services to customers. The success of the company in achieving its goals is not only determined by employee behavior towards the tasks in their job description (in role behavior), but also the behavior of employees towards tasks outside of their job description (extra behavior). The demand for nurses to achieve these tasks has made nurses one of the elements of the hospital that desperately needs organizational citizenship behavior (Runtu and Widyarini 2009). Organizational Citizenship Behavior (OCB) according to Organ et al. (2006) is the behavior of employees serving well based on a voluntary action, done sincerely and happily, without having to be governed or controlled by the company. OCB is reflected through employee behavior that is not required in their job description (in role behavior) and is not compensated by the company's management (Podsakoff et al. 2009).

One of the things that can trigger OCB is the job satisfaction felt by employees. Organ and Ryan (1995) emphasized job satisfaction as one of the variables affecting OCB. According to Wexley and Yuki (1988) job satisfaction is the feeling or sentiment of an employee regarding his work, encapsulating everything he faces in his work environment. Job satisfaction reflects the feeling of being happy or unhappy about an employee's work and can affect employee motivation to attend and mobilize their energy, mind, and time in carrying out their work. One factor that could maintain job satisfaction and OCB is compensation. Compensation is the main factor in motivation that supports job satisfaction and OCB because compensation is something that employees receive as a substitute for their service and contribution to the company (Rivai 2004). One form of compensation provided by the company is by providing incentives to encourage employees to keep on achieving better. Employees work because they are encouraged to make ends meet, so they will work to get rewards in the form of incentives provided by the company. With the provision of incentives, employees feel that they get the attention and recognition of their accomplishments so that their morale and loyalty can be improved.

A hospital generally consists of various units with a multitude of job description and workload. One of such unit at the hospital is the inpatient care unit. Inpatient care is a work unit that has a relatively greater burden than the other work units, because patients who stays for more than a day at the hospital will increase the amount of responsibility for the nurses. These nurses will have to take care in managing their patient's treatment, hygiene, and administration. The difference in the workload of this unit with the other units sometimes results in differences in the amount of incentives actually given to the nurses and the magnitude of the nurses' expectation of their own incentives. The nurses' acceptance in getting their incentives, which differ from their expectations, can affect the nurses' job satisfaction. Therefore, it is necessary to examine whether differences in incentive systems will affect job satisfaction and can affect OCB. The purpose of this study was to analyze the effect of nurses' perceptions on the incentive system and job satisfaction on OCB.

\section{METHODS OF RESEARCH}

This research was conducted in a Government Hospital in Bogor City which was conducted in August 2018 - October 2018. Primary data was obtained from questionnaires on 100 nurses who were selected purposively under the criteria that the nurses had worked for more than a year. Primary data is also obtained from in-depth interviews with many informants who knows about the incentive system at the hospital. Secondary data is obtained from the institution concerned.

Data processing and analysis is done by instrument testing, descriptive analysis, and PLS to analyze SEM models. The instrument test was conducted to determine the validity and reliability of the questionnaire, this was done by testing the items in the questionnaire given to the respondents. If declared valid, then the question is used for the next discussion. Based on the validity test, all of the questions in this study (43 indicators) are declared valid. The results of reliability testing on all indicators on the variables used in the study can be accepted at 0.975 , so the reliability of the questionnaire questions is considered as good. 
The study began by analyzing nurses' perceptions on the system of incentives, job satisfaction, and OCB. Indicators of nurse perceptions on the incentive system are also influenced by individual characteristics. Based on the aim of the study to analyze the effect of nurses' perceptions on the incentive system and job satisfaction on OCB, the following hypotheses were formulated. $(\mathrm{H} 1)$ Nurses' perceptions of the incentive system had an effect on job satisfaction, (H2) Job satisfaction had an effect on OCB, (H3) Nurses 'perceptions of the incentive system have an effect on OCB, and (H4) Nurses' perceptions of the incentive system have an effect on OCB through job satisfaction.

Analysis of the data used is Structural Equation Modeling (SEM) with the partial least square (PLS) approach using SmartPLS 3.0 software. PLS is a component or variant based model. According to Ghozali (2006), PLS is an alternative approach that shifts from a covariant-based SEM approach to a variant based approach. To analyze this research, several stages were conducted (Ghozali 2006), namely evaluation of the measurement model or outer model, evaluation of the structural model or inner model, and hypothesis testing.

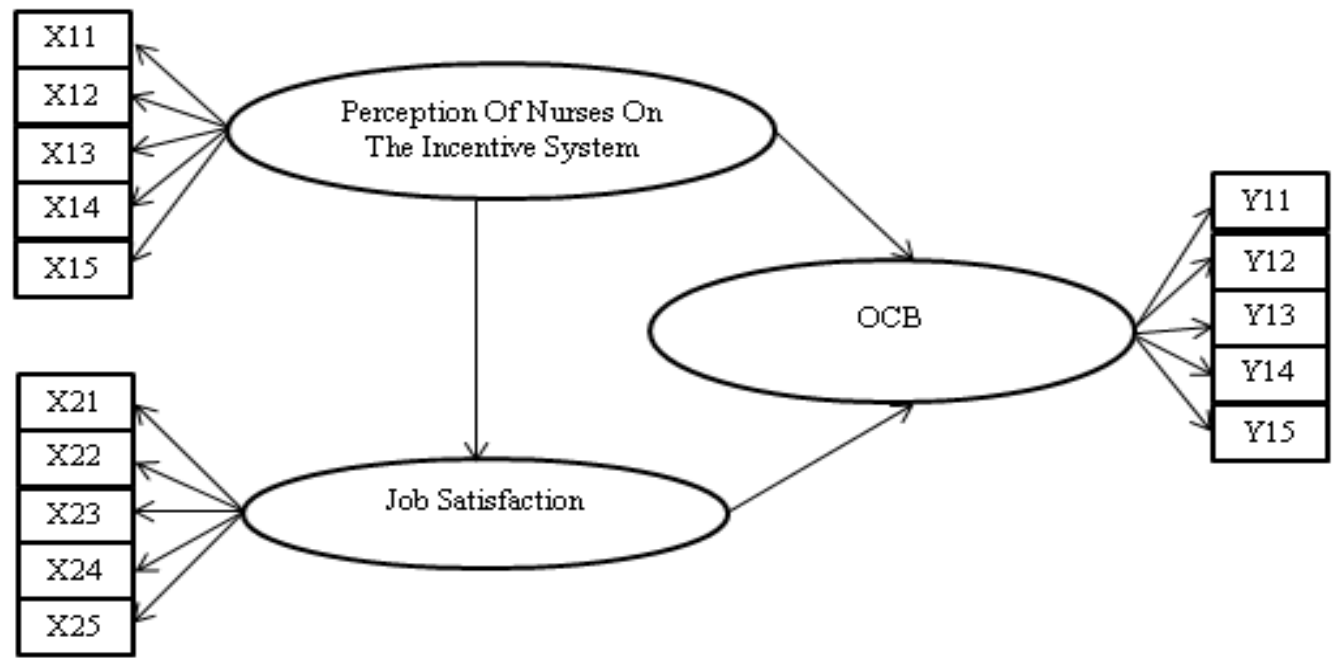

Figure 1 - Structural model

The variable perception of nurses on the incentive system with the forming component consists of: $\mathrm{X} 11=$ Magnitude, $\mathrm{X} 12=$ Justice, $\mathrm{X} 13=$ Requirement, $\mathrm{X} 14=$ Timeliness, and $\mathrm{X} 15=$ Increase in incentives.

Job satisfaction variables with forming components consist of: $\mathrm{X} 21=$ Payment, $\mathrm{X} 22=$ Promotion opportunity, X23 = Job, X24 = Supervisor, and X25 = Colleague.

OCB variables with forming components consist of: $Y 11=$ Altruism, $Y 12=$ Courtesy, Y13 = Civic Virtue, Y14 = Conscientiousness, and Y15 = Sportmanship.

\section{RESULTS AND DISCUSSION}

According to the World Health Organization (WHO), hospitals are an integral part of a social and health organization with the function of providing comprehensive services, healing (curative), and disease prevention to the public. The hospital is also a training center for health workers and medical research centers. The Government of the Republic of Indonesia defines a hospital as a health service institution that organizes personal health services in a comprehensive manner that provides inpatient, outpatient, and emergency services (Government of the Republic of Indonesia 2009). Nurses are health workers. The nurse is someone who has completed a nursing education program both at home and abroad that is recognized by the Government of the Republic of Indonesia, registered and authorized to carry out nursing practices in accordance with the laws and regulations. The nurse in the hospital has a 24-hour shift system. The duties and responsibilities of a nurse include 
nursing therapy, nursing observation, complementary therapy, health education, advice, and counseling (PPNI Center Management 2005).

The 2010 Minister of Health Regulation states that hospitals in Indonesia can be divided into two types based on ownership, namely:

Government-owned hospital, which includes:

- Central Hospital of the Ministry of Health;

- Regional Hospital belonging to the Provincial Government;

- Regional Hospital owned by the Regency / City Government;

- Hospital belonging to the Indonesian National Army (TNI);

- Hospital belonging to the Police of the Republic of Indonesia;

- Hospitals belonging to departments outside the Ministry of Health, including those belonging to State-Owned Enterprises.

Private hospitals, which include:

- Foundation-owned Hospital;

- Hospital owned by a Company;

- Hospital owned by investors (domestic and foreign);

- Hospital belonging to another Legal Entity.

The hospital in this study is classified as a government-owned hospital. At present, this hospital employ approximately 200 nurses for inpatient care. The working hours in this hospital are no different from other hospitals in general, divided into three shifts: 07.0014.00, 14.00-21.00, and 21.00-07.00 (GMT+7). In between shifts, nurses are to voluntarily communicate in advance with other nurses. The break system applied on this hospital is 2 days, 2 noon, and 2 nights for every month. In each inpatient room, there is a group that consists of the head of the room, two team heads, and each team head has members. The inpatient room in the hospital is divided into 13 rooms, namely the obstetrics room, baby room, high care unit (HCU) room, operating room, guard post, USG, recovery room, and several other inpatient room (Wira, Hesti, Garuda Atas, Garuda Bawah, Cakti, and Kartika room). The results of data collection from the questionnaire has shown several characteristics based on the demographic data as shown in Table 1.

Table 1 - Distribution of respondents based on demographic aspects

\begin{tabular}{llll}
\hline Information & Respondent Group & Number of people & Percentage (\%) \\
\hline \multirow{3}{*}{ Age } & $\leq 25$ & 21 & 21 \\
& $26-35$ & 58 & 58 \\
& $>35$ & 21 & 21 \\
\hline \multirow{2}{*}{ Gender } & Man & 25 & 25 \\
& Women & 75 & 75 \\
\hline \multirow{3}{*}{ Level of education } & SMA & 4 & 4 \\
& Diploma & 62 & 62 \\
& S1 & 34 & 34 \\
Years of service & $1-5$ & 42 & 42 \\
& $6-10$ & 43 & 43 \\
& $>10$ & 15 & 15 \\
\hline \multirow{3}{*}{ Position } & Nurse section head & 1 & 1 \\
& Head of the room & 11 & 11 \\
& Head of the team & 13 & 13 \\
& Member & 75 & 75 \\
\hline
\end{tabular}

Based on Table 1, the distribution of the largest age of respondents is 26 -35 years with a percentage of $58 \%$. This shows that most respondents are nurses who are in their productive age. Based on the gender demographic aspect, the number of nurses was mostly women with a percentage of $75 \%$. In the level of education, $62 \%$ of nurses have a Diploma background which shows that some nurse in the hospital have had fairly good education. 
Then based on job tenure, $58 \%$ of nurses have a worked for more than 6 years. This shows that some nurses have good loyalty to the hospital. These nurses were divided into 4 groups of positions: nurse section heads $(1 \%)$, room heads $(11 \%)$, team heads $(13 \%)$, and members (75\%).

Data Analysis with PLS-SEM. The exogenous latent variable in this study consisted of two variables, namely the perception of nurses on the incentive system and job satisfaction. The perception of nurses in the incentive system is a variable that has 5 indicators (X11 to $\mathrm{X} 112$ ) and job satisfaction is a variable with of 5 indicators (X21 to X211). The endogenous latent variable in this study is OCB, with 5 indicators (Y11 to $Y 120)$. These indicators will later be developed into several questions arranged in the research questionnaire.

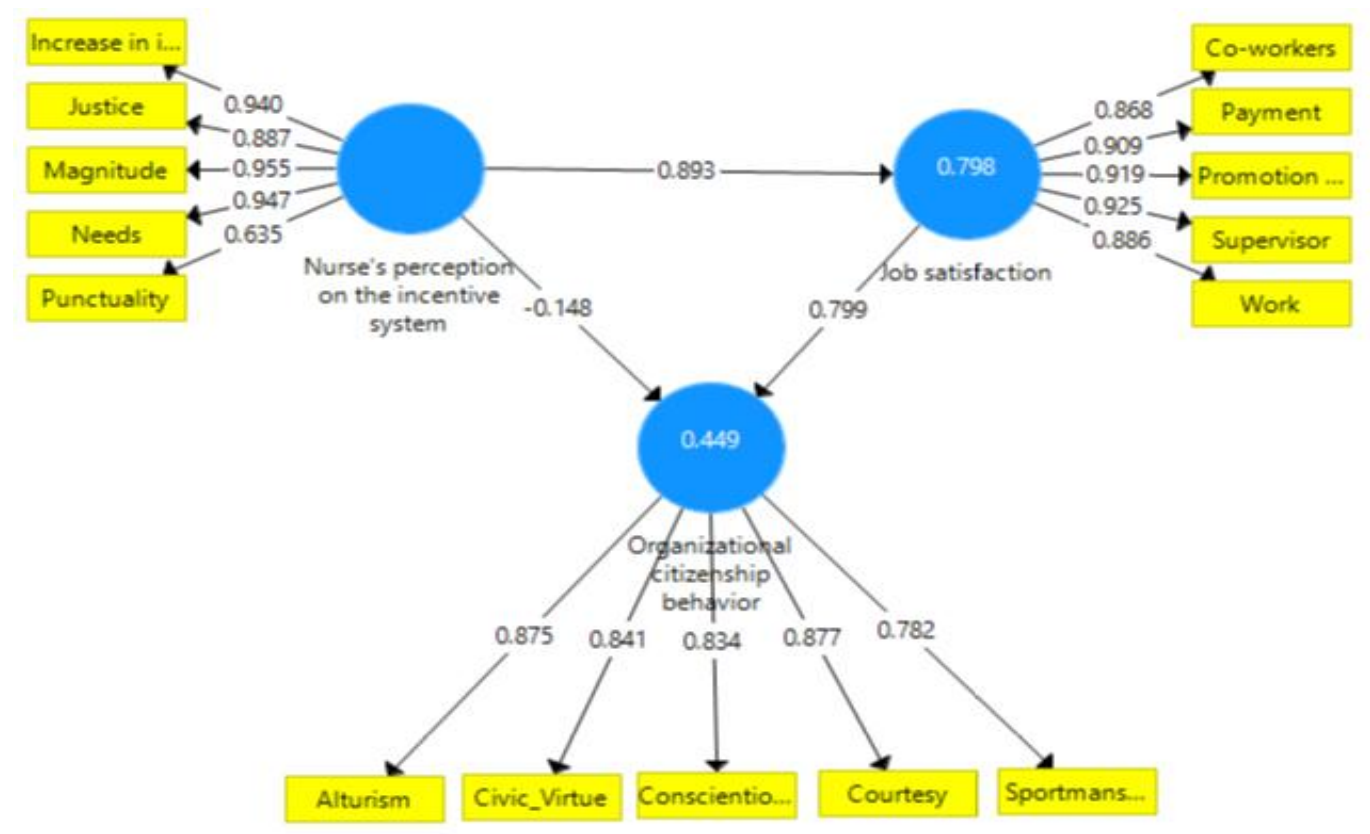

Figure 2 - Loading factor on the measurement model

According to Ghozali (2008), if there are indicators that have a loading factor value of $<0.5$, recalculation must be performed on the initial model so that the loading factor of all reflective indicators is $>0.5$ as a criterion of the convergent construct validity test. The model in Figure 2 shows that there are no indicators that have a loading factor value of $<0.5$, which means that the indicators used have properly described latent variables.

Table 2 - Results of Iteration of Final Measurements of Nurse Perception Variables in Incentive Systems

\begin{tabular}{ll}
\hline Indicator & Loading Factor \\
\hline Magnitude & 0.955 \\
Justice & 0.877 \\
Needs & 0.947 \\
Punctuality & 0.635 \\
Increase in incentives & 0.940 \\
\hline
\end{tabular}

Perception is someone's view of an event, where perception is formed by hope and experience. Individual perceptions in the same situation can be different. This happens because each individual is unique, has different sets of values, and differing life experiences, so that the reception and interpretation produced can be different. Nurse perceptions according to Potter and Perry (2005) are nurses' views, feelings, interpretations, and understanding of what happens to clients and the environment. 
According to the Minister of Health Regulation No. 1199 of 2004 concerning guidelines for the procurement of health workers with work agreements, it was explained that incentives are meant to provide compensation to health workers for their work outcomes that exceeded the average, in order to increase the output of health facilities. The incentives are different from working overtime. Determination of incentives is not easy because it is difficult to measure the parameters for reward. Incentives are only given to certain personnel included in the incentive program. The criteria for providing incentives according to Minister of Health Regulation No. 1199 of 2004 is that there is a workload that must be resolved, which is set out in an incentive program to increase productivity within the time period, with clear parameters, and health workers who enter the program are selected individuals. Incentive payments are paid outside of salary payments.

According to Simamora (2006) the factors that influence the provision of incentives are the magnitude of incentives, increase in incentives, accuracy, fluency, fairness, and feasibility. Furthermore, according to Hasibuan (2013), the basic considerations for preparing incentives includes performance, length of work, seniority, needs, fairness, feasibility, and job evaluation. In order to provide incentives in accordance with the expectations of the desired perception of nurses, the indicators of nurses' perceptions of the incentive system were adapted from various experts and adjusted as magnitude, fairness, needs, time provisions, and increase in incentive.

The results in Table 2 shows that magnitude has the highest value at 0.955 . This shows that the magnitude of the incentive system in a hospital plays an important and influential role in the assessment of nurses who are in the hospital. Magnitude and giving good incentives can help create a good work process and set achievements such as work goals, so that nurses can receive job satisfaction which will positively impact organizational citizenship behavior.

Table 3 - Final Iteration Results for Variable Measurement of Job Satisfaction

\begin{tabular}{ll}
\hline Indicator & Loading Factor \\
\hline Payment & 0.909 \\
Promotion opportunity & 0.919 \\
Work & 0.886 \\
Supervisor & 0.925 \\
Co-workers & 0.868 \\
\hline
\end{tabular}

According to Kreitner and Kinicki (2014), job satisfaction is an affective or emotional response to various aspects of one's work. The level of work satisfaction of each employee is different, because the standard of satisfaction of each individual also differs from one another. Job satisfaction as an individual feeling can generally be associated with work (Robbins 2008). The positive and negative feelings of work is an evaluation process that happens internally within a person, therefore, job satisfaction can bring out a pleasant or unpleasant feeling that is felt by an individual to their working conditions. According to Colquitt et al. (2013) job satisfaction is a condition of emotional satisfaction from the results of one's assessment of work and work experience.

The measurement of job satisfaction has several views, according to Colquitt et al. (2013) there are two elements contained in job satisfaction, namely value fulfillment and satisfaction with the work itself. Employees feel satisfied if their work can provide something they can value, something that is valuable is something that will make people want to find or get it, both consciously or unconsciously. Job satisfaction will occur if workers feel that the value they want will be fulfilled which can be obtained, but different people appreciate different things and their value can change during life and work. The theory concerned with fulfilling this value is value-percept theory. Value-percept theory explains that someone evaluates job satisfaction based on certain aspects of work. Meanwhile, work is not only based on one aspect but is a collection of tasks, relationships, and awards. So to measure 
job satisfaction according to value-percept theory is with payment satisfaction, promotion satisfaction, supervision satisfaction, coworker satisfaction, and job satisfaction.

Table 3 shows the results for the variable of job satisfaction, with supervisor having the highest value with 0.925 . This shows that supervisor is the indicator that affects the variable job satisfaction the most, as a good supervisor will positively impact the job satisfaction that an employee gets, so that it will affect organizational citizenship behavior. The highest value of this indicator shows that employees are satisfied with the relationship between the supervisor.

Table 4 - Final Iteration Results for Organizational Citizenship Behavior

\begin{tabular}{ll}
\hline Indicator & Loading Factor \\
\hline Altruism & 0.875 \\
Conscientiousness & 0.834 \\
Sportmanship & 0.782 \\
Courtesy & 0.877 \\
Civic Virtue & 0.841 \\
\hline
\end{tabular}

Organ (1994) states that OCB are behaviors carried out by organizational members or employees who are not expressly rewarded if they do so and are not punished if they do not do so, as the behavior carried out is not part of the job description of the employees, and it is the behavior of employees that they implemented without training in advance. Organ (1988) defines OCB as a behavior that is not related to the formal reward system of an organization but drives the organization effectively. Organ states that OCB may at some point encourage the occurrence of rewards, but these rewards are uncertain.

OCB consists of 5 dimensions (Organ et al 2006), namely altruism, conscientiousness, sportmanship, courtesy, and civic virtue. Altruism is a behavior that alleviates work aimed at colleagues. Courtesy is a behavior that prevents problems with colleagues. Civic virtue is the behavior of self-involvement and responsibility in the activities of the organization and care for the continuity of the organization. Conscientiousness is the behavior of doing things that benefit the organization beyond the minimum requirements needed. Sportsmanship is a behavior that tolerates situations that are less ideal or uncomfortable at work without complaining. The measurement results (Table 4) show that the courtesy indicator has the highest value that is equal to 0.877 , making the indicator the most influential on OCB.

Table 5 - Average value of variance extracted (AVE) and composite reliability

\begin{tabular}{lll}
\hline Latent variable & AVE & Composite Reliability \\
\hline Nurse's perception on the incentive system & 0.776 & 0.945 \\
Job satisfaction & 0.813 & 0.956 \\
Organizational citizenship behavior & 0.710 & 0.924 \\
\hline
\end{tabular}

Table 5 shows the AVE value and composite reliability. The model is said to be good if it meets the requirements of validity and reliability. The model has good validity if each latent variable with a reflective indicator has $A V E>0.5$, while it will be reliable if the latent variable has a composite reliability value of more than 0.7 . The analysis shows that the AVE value of each latent variable has a value $>0.5$ and all latent constructs have a composite reliability value of more than 0.7 so it can be said that the PLS model met a good convergent validity and has good, accurate, and consistent reliability.

In addition to testing validity and reliability, discriminant validity is also tested. Testing of discriminant validity is carried out by the principle that different constructs (manifest variables) should not be highly correlated (Ghozali 2008). One way to test discriminant validity is to compare the root values of average variance extracted (AVE) of each construct with a correlation between constructs and other constructs. The results of the analysis in 
Table 6 shows that the AVE root value is higher for the correlation between constructs and other constructs, so that it can be said that the model meets the requirements of discriminant validity.

Table 6 - AVE values and AVE roots

\begin{tabular}{lll}
\hline Latent variable & AVE & VAVE \\
\hline Nurse's perception on the incentive system & 0.776 & 0.881 \\
Job satisfaction & 0.813 & 0.902 \\
Organizational citizenship behavior & 0.710 & 0.843 \\
\hline
\end{tabular}

Evaluation of Structural Models (Inner Model). Testing the inner model or structural model is done by looking at the R-square of the research model. Data from the R-square estimation can be seen in Table 7.

Table 7 - R-square values

\begin{tabular}{lll}
\hline & $R$-square & $R$-square Adjusted \\
\hline OCB & 0.449 & 0.437 \\
Job satisfaction & 0.798 & 0.796 \\
\hline
\end{tabular}

Job satisfaction and perceptions of nurses on the incentive system were able to explain OCB diversity by $43.7 \%$, while $56.3 \%$ was explained by other independent variables outside the model. While the perception of nurses on the incentive system is able to explain the diversity of job satisfaction by $79.8 \%$, the remaining $20.2 \%$ is explained by other independent variables outside the model.

Hypothesis testing. Subsequent tests in the evaluation of inner models or structural models are carried out to see the significance of the path coefficients that show the relationship or influence between latent variables in the study. In PLS, testing each relationship is done using a simulation with the bootstrapping method of the sample. The test results with the bootstrapping method for path coefficients from PLS SEM analysis can be seen in Table 8.

Table 8 - Path coefficients between latent variables

\begin{tabular}{llllll}
\hline & Original Sample (O) & Sample Mean $(\mathrm{M})$ & $\begin{array}{l}\text { Standard } \\
\text { Deviation (STDEV) }\end{array}$ & T-Statistic & $P$-Values \\
\hline PPSI $\rightarrow$ KK & 0.893 & 0.895 & 0.017 & 51.743 & $0.000^{*}$ \\
KK $\rightarrow$ OCB & 0.799 & 0.810 & 0.148 & 5.399 & $0.000^{*}$ \\
PPSI $\rightarrow$ OCB & -0.418 & -0.152 & 0.155 & 0.954 & 0.341 \\
PPSI $\rightarrow$ KK $\rightarrow$ OCB & 0.566 & 0.573 & 0.051 & 11.164 & $0.000^{*}$ \\
\hline
\end{tabular}

Note: *) significant influence on alpha level 5\%.

The results of the analysis (Table 8 ) shows the perception of nurses on the incentive system to have a positive or direct effect on job satisfaction with a coefficient of 0.893 . This result is significant at $5 \%$ alpha level because the $p$-value $(0.000)$ is smaller than $(0.05)$. This shows that the more positive the nurse's perception on the incentive system, the nurse's job satisfaction will increase. In line with research from Fitria (2017) which states that there is a positive and significant relationship between incentives and job satisfaction, where nurses who have a good perception of giving incentives will have high job satisfaction and work motivation in realizing and supporting the achievement of hospital goals. Based on the results of the path coefficients, the first hypothesis in this study states that nurses' perceptions of the incentive system have an effect on acceptable job satisfaction in hospitals. 
Job satisfaction with OCB also has a positive or direct effect with a coefficient of 0.799 . This result is significant at $5 \%$ alpha level because the p-value $(0.000)$ is smaller than $(0.05)$. This shows that the more positive the nurse's job satisfaction, the behavior of OCB on nurses will increase. In line with the research conducted by Fitriana, et al. (2013) from the results of the study there is a positive and significant influence between job satisfaction on OCB. Someone with a high level of job satisfaction shows a positive attitude towards work, so that nurses who do not get job satisfaction will never achieve psychological satisfaction and eventually negative behavior will arise which. Conversely, satisfied nurses can work well, full with enthusiasm. Based on the results of the path coefficients, the second hypothesis in this study which states that job satisfaction influences OCB in hospitals can be accepted.

The perception of nurses on the incentive system towards OCB has a negative or opposite effect with a coefficient of -0.418 . This result is not significant at $5 \%$ alpha level because the $p$-value $(0.341)$ is greater than $(0.05)$. This shows that nurses' perceptions on the incentive system are not directly and in the opposite direction of their influence on OCB. Organ (1988) defines OCB as free behavior, not directly related to the reward system and can improve the effective functioning of the organization. This is in line with Hasibuan's research (2009) which states that there is no significant direct effect of incentive satisfaction on organizational commitment and OCB, except through job satisfaction. Based on the results of the path coefficients, the third hypothesis in this study which states that the perception of nurses on the incentive system has an effect on OCB in the hospital is rejected.

Nurses' perceptions on the incentive system towards OCB that are influenced by job satisfaction have a positive or direct effect with a coefficient of 0.566 . This result is significant at $5 \%$ alpha level because the p-value $(0.000)$ is smaller than $(0.05)$. So, in building OCB behavior on nurses, there must be a close relationship between nurses' perceptions of the incentive system and job satisfaction, then job satisfaction with OCB, so that OCB will be done by the nurses. This shows that the more positive the perception of nurses on the incentive system, the higher job satisfaction that will increase OCB. Job satisfaction in this research is a variable that functions as an intervening variable. Based on the results of the path coefficients, the fourth hypothesis in this study states that nurses' perceptions on the incentive system have an effect on OCB through job satisfaction in hospitals can be accepted. This is supported by the results of interviews with nurses who has stated that there are some dissatisfaction with the incentive system in terms of timely payment. The delay in payment affects the job satisfaction of nurses, which in turn affects the behavior of OCB nurses.

Managerial Implications. Based on the results of the research that has been done, it is known that there is an influence between nurses' perceptions on the incentive system and job satisfaction towards OCB. The results showed that the more positive the perception of nurses on the incentive system, the higher the job satisfaction that would in turn increase OCB in nurses. Efforts can be made by the hospital's management to improve nurses' perceptions of the incentive system and job satisfaction so as to increase OCB, among others:

Hospital management should evaluate the incentive system periodically given to nurses by the hospital to be able to improve the nurses' perceptions of the incentive system. This is based on the results of loading factors that show aspects of magnitude with a high value in shaping the level of perception of nurses on the incentive system, so that the hospital can always strive for nurses to feel sufficient about the amount of incentives received in accordance with the performance achieved, the amount of incentives in accordance with the nurses' expectations, and incentives provided in accordance with applicable hospital regulations.

Hospital management conducts focus group discussion (FGD) activities routinely by involving leaders and employees so that leaders can conduct routine guidance, direction, and supervision of employees. This is based on the results of job satisfaction loading factor, where the supervisor's aspect turns out to have the highest influence on job satisfaction. The 
leadership figure is instrumental in the application of OCB because the leader can be a role model for nurses and inspire OCB.

Open equal opportunities for all nurses to be promoted by increasing nurse competency through training and development. This is based on the results of loading factors, the promotion opportunity as an indicator of job satisfaction has the second highest value among other job satisfaction indicators, and doing so could increase nurses' job satisfaction and increase OCB.

Courtesy is the most influential indicator of OCB formation for nurses in hospitals, therefore hospital management needs to maintain it by giving instructions to nurses to always maintain the good name and image of the hospital, mutual respect for policies that are in the hospital, mutual respect between other nurses, and always maintain an attitude not to disturb the other nurses.

\section{CONCLUSION AND RECOMMENDATIONS}

The nurses' perceptions on the incentive system had an effect on organizational citizenship behavior through job satisfaction. The more positive of a perception the nurses has on the incentive system, the higher job satisfaction would be, and that would improve organizational citizenship behavior in nurses.

Based on the results of the study, job satisfaction is an important thing that every nurse must have to increase their OCB. Job satisfaction can be achieved by an increase in payments, opportunities for promotions, supervisor, colleagues, and jobs. Then, future researches could expand the object of research on similar industries (hospitals) to be able to get an overview of organizational citizenship behavior in nurses in the industry. Further research may also consider other factors that influence organizational citizenship behavior such as employee recruitment systems, facilities available in hospitals, the relationship between nurses and patients, leadership style, organizational culture, and employee performance.

\section{REFERENCES}

1. Atmawati R, Wahyudin M. 2007. Analisis pengaruh kualitas pelayanan terhadap kepuasan konsumen pada Matahari Departement Store di Solo Grand Mall. Surakarta: Jurnal Daya Saing, Program MM-UMS.

2. Colquitt J, Lepine J, Wesson MJ. 2013. Organization Behavior: Improving Performance and Commitment in The Workplace. New York (US): McGraw-Hill.

3. Depkes, RI. 2004. Petunjuk Pelaksanaan Kepmenkes No 1199/2004 Tentang Pedoman Pengadaan Tenaga Kesehatan Dengan Perjanjian Kerja. Direktorat Jenderal Pelayanan Medik, Direktorat Pelayanan Keperawatan.

4. Fitria, Jimmy. 2017. Pengaruh reward, insentif, pembagian tugas dan pengembangan karier pada kepuasan kerja perawat di Rumah Sakit Ortopedi Prof. Dr. R. Soeharso Surakarta. [tesis]. Surakarta (ID): Universitas Sebelas Maret.

5. Fitrianasari, Diana. Nimran, Umar. Utami, Hamidah Nayati. 2013. Pengaruh kompensasi dan kepuasan kerja terhadap organizational citizenship behaviour. Jurnal Profit Volume 7 No.1 Universitas Brawijaya.

6. Ghozali, Imam. 2006. Structural Equation Modeling, Metode Alternatif dengan Partial Least Square. Edisi 2. Semarang (ID): Badan Penerbit Undip.

7. Ghozali, Imam. 2008. Structural Equation Modeling, Metode Alternatif dengan Partial Least Square. Semarang (ID): Badan Penerbit Undip.

8. Gronross. 2000. Service Management and Marketing. London (EN): John Wiley and Sons Ltd.

9. Hasibuan, Rafika Siti. 2009. Pengaruh budaya organisasi dan kepuasan insentif terhadap komitmen organisasi, organizational citizenship behaviors dan kepuasan kerja karyawan Pusat Penelitian Kelapa Sawit Sumatera Utara. [tesis]. Bogor (ID): Institut Pertanian Bogor. 
10. Hasibuan M. 2013. Manajemen Sumber Daya Manusia. Edisi Revisi. Jakarta (ID): PT Bumi Aksara.

11. Kreitner R, Kinicki A. 2014. Perilaku Organisasi. Buku ke 1. Biro Bahasa Alkemis, penerjemah. Jakarta (ID): Salamba Empat. Terjemahan dari: Organizational Behavior. Ed ke 9.

12. Organ, DW. 1988. Organizational citizenship behavior: The good soldier syndrome. Lexington MA (US): Lexington Books.

13. Organ DW. 1994. Personality and organizational citizenship behavior. Journal of Management. 20: 465-78.

14. Organ DW, Ryan K. 1995. A meta-analytic review of attitudinal and dispositional predictors of organizational citizenship behavior. Personnel Psychology. 48: 775-802.

15. Organ, DW, Podsakoff PM, MacKenzie SB. 2006. Organizational Citizenship Behavior: Its Nature, Antecedents, and Consequences. California (US): Sage Thousand Oaks.

16. Pemerintah Republik Indonesia. 2009. Undang-undang Republik Indonesia nomor 44 tahun 2009 tentang Rumah Sakit. Jakarta (ID): Sekretariat Negara.

17. Pemerintah Republik Indonesia. 2010. Peraturan Menteri Kesehatan (Permenkes) nomor 340 tahun 2010 tentang Klasifikasi Rumah Sakit Umum. Jakarta (ID): Sekretariat Negara.

18. Pengurus Pusat PPNI. 2005. Standar Kompetensi Perawat Indonesia. Jakarta (ID): Sekretariat PPNI. http://www.inna-ppni.or.id.

19. Podsakoff NP, Whiting SW, Podsakoff PM, Blume BD. 2009. Individual and organizational-level consequences of organizational citizenship behaviors: A meta analysis. Journal of Applied Psychology. 94(1): 122-141. doi: 10.1037/a0013079.

20. Potter dan Perry. 2005. Fundamentals of Nursing: Concept, Prosess, and Practice $\left(4^{\text {th }}\right.$ ed). Philadelphia (US): Mosby Year Book.

21. Rivai, V. 2004. Manajemen Sumber Daya Manusia Untuk Perusahaan dari Teori ke Praktik. Jakarta (ID): PT. Raja Grafindo Persada.

22. Robbins SP, Judge TA. 2008. Perilaku Organisasi. Edisi 12. Jakarta: Salemba Empat.

23. Runtu DYN, Widyarini MMN. 2009. Iklim organisasi, stress kerja dan kepuasan kerja pada perawat. Jurnal Psikologi. 2 (2).

24. Simamora H. 2006. Manajemen Sumber Daya Manusia. Edisi 2. Yogyakarta (ID): STIE YKPN Yogyakarta.

25. Wexley KN, Yukl LA. 1988. Organizational Behavior and Personnel Psychology. Boston (US): Richard D. Irwin, Inc. 